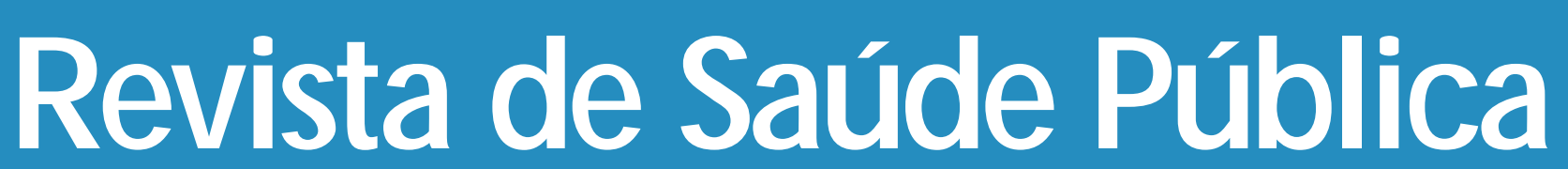

$\begin{array}{lllllll}J & O & U & R & N & A & L\end{array}$

0 F

$\mathbf{P} \mathbf{U}$

B L I C

H E A L T H

\title{
Influence of HIV positive status on sexual behavior among males*
}

\section{Influência do teste HIV positivo no comportamento sexual em homens}

Elvira M.Ventura-Filipe and Stan P. Newman

Programa Estadual de DST/AIDS. São Paulo, SP - Brasil (E.M.V.F.), Health Psychology Unit, Department of Psychiatry and Behavioural Sciences - UCL Medical School, London, UK (S.P.N.)

M.AND Elvira Ventura-Filipe Stan P. Newman Influence of HIV positive status on sexual behavior among males*Rev. Saúde Pública, 32 (6): 503-13, 1998

(c) Copyright Faculdade de Saúde Pública da U SP. Proibida a reprodução mesmo que parcial sem a devida autorização do Editor Cient́fico. Proibida a utilização de matérias para fins comerciais. All rights reserved. 


\title{
Influence of HIV positive status on sexual behavior among males*
}

\section{Influência do teste HIV positivo no comportamento sexual em homens}

\author{
Elvira M.Ventura-Filipe and Stan P. Newman \\ Programa Estadual de DST/AIDS. São Paulo, SP - Brasil (E.M.V.F.), Health Psychology U nit, Depart- \\ ment of Psychiatry and Behavioural Sciences - UCL M edical School, London, UK (S.P.N.)
}

\begin{abstract}
Objective To compare HIV seronegative (HIV-) and HIV seropositive (HIV+) males in terms of sexual behavior with female and male partners of different types.

Method Cross-sectional study. From August 1994 to February 1995, a sample of 236 respondents (150 HIV- and $86 \mathrm{HIV}+$ ) recruited from public health centers in the State of S. Paulo (Brazil), answered a questionnaire, including questions on demographic aspects, HIV and AIDS related knowledge, sexual orientation, use of alcohol and other drugs, sexual behavior with regular and casual female and male partners, and perceived risk of HIV infection. Sexual behavior with regular and casual female and male partners within the previous three months, was investigated.
\end{abstract}

Results A lower proportion of HIV+ engaged in sexual contact with regular female partners $(\mathrm{p}<.01)$ and in vaginal intercourse with this type of partner $(\mathrm{p}<.01)$. A lower proportion of HIV+ engaged in overall sexual activity $(\mathrm{p}<.001)$ and reported lower frequency of penetrative sexual practices $(p<.05)$. A high level of condom use with female and male partners was identified with no significant differences being found between the two serostatus groups. Some risky sexual behavior was identified, however, especially with regular partners, suggesting that some men were continuing to practice unsafe sex.

Conclusions

The high level of condom use identified suggests that safer sex advice has been taken up. Condom use was not universal, however, and some men continue to place themselves at risk, especially with regular partners. Prevention programs should strive not only to encourage HIV- to practice safer sex, but also to encourage HIV+ to do so in order to prevent further transmission of the virus.

AIDS serodiagnosis. Sex behavior. Risk-taking.

*Supported by "Conselho Nacional de Desenvolvimento Científico e Tecnológico/CNPq" and the Central Research Fund of the University of London. Correspondence to: Elvira M. Ventura-Filipe - Rua Santa Cruz, 81 - 04121-000 São Paulo, SP - Brasil. E-mail: efilipe@ ccbinet.com.br The publication of this article was supported by "FAPESP (Process n ${ }^{\circ}$ 97/09815-2)".

Submitted on 29.10.1997. Reviewed on 14.4.1998. Approved on 28.5.1998. 


\begin{abstract}
Resumo
Objetivo Comparar homens HIV soronegativos (HIV) e HIV soropositivos (HIV+) em termos de comportamento sexual com parceiras e parceiros regulares e casuais.

Método $\quad$ Estudo transversal. De agosto de 1994 a fevereiro de 1995, uma amostra de 236 participantes (150 HIV-e $86 \mathrm{HIV+}$ ) foi recrutada de serviços públicos do Estado de São Paulo, Brasil, para atendimento e testagem de HIV/AIDS. Foi aplicado aos participantes questionário contendo questões sobre aspectos demográficos, conhecimento sobre HIV e AIDS, orientação sexual, uso de álcool e outras drogas, percepção de risco para HIV e comportamento sexual com parceiros $e$ parceiras regulares e casuais (investigado nos últimos três meses).

Resultados A comparação entre os indivíduos HIV+e HIV indicou que uma menor percentagem de HIV+ teve contato sexual com parceiras regulares $(p<.01)$, praticou sexo vaginal com este tipo de parceira $(p<.01)$ e praticou todo tipo de atividade sexual $(p<.001)$. Os indivíduos HIV+ relataram uma freqüência menor de práticas sexuais penetrativas $(p<.05)$. Identificou-se um nível elevado de uso de preservativo com parceiras e parceims sexuais e não foi observada diferença significativa entre os dois grupos neste aspecto. Identificou-se algum comportamento de risco, especialmente com parceiros/ parceiras regulares.

Conclusões $\quad O$ nível elevado de uso de preservativo sugere que têm sido adotadas recomendações em relação a sexo seguro. $O$ uso de preservativo não foi universal sugerindo que alguns homens continuam a praticar sexo desprotegido. A efetiva prevenção da transmissão do vírus ocorrerá com programas de prevenção que estimulem práticas de sexo seguro entre indivíduos $\mathrm{HIV}$ - e HIV+.
\end{abstract}

Sorodiagnóstico da AIDS. Comportamento sexual. Correr o risco.

\section{INTRO DUCTION}

Primary prevention efforts aiming at controlling the spread of the Human Immunodeficiency Virus (HIV) have been directed at promoting modifications in people's attitudes and behaviors. The effect of knowledge of HIV antibodies as a means of reducing risk behavior has been addressed in several studies with mixed findings. Various studies have documented reduction in the number of partners ${ }^{2,27}$ and an increase in condom use ${ }^{8,17,20,26}$ among HIV seropositives as compared with HIV seronegatives. By contrast, awareness of HIV status has been found to have no the effect on the number of partners ${ }^{25,29}$ or on condom use ${ }^{9}$ in other studies.

Despite the great number of AIDS cases in Brazil $^{18}$ and the high prevalence of HIV $^{5,19}$ no studies have been found on the influence of an HIV positive status on sexual behavior in the country.

This cross-sectional study has been designed to compare the sexual behavior of HIV seronegative and HIV seropositive males with female and male partners focusing on the adoption of safe sex in both groups. The hypothesis that HIV seropositives would practice less risky sexual behavior due to concern about transmitting the virus has been advanced.

\section{METHOD}

From August 1994 to February 1995, 236 HIV seronegative (HIV-) and HIV seropositive (HIV+) males were recruited from public health services for HIV testing or centers for follow-up treatment of HIV and AIDS in the State of S. Paulo, Brazil. For HIV+, the inclusion criterion was to have never experienced any opportunistic infections. For HIV-, the criterion was to have received a negative HIV test result immediately before the interview.

Information was obtained by verbal administration of an anonymous questionnaire. Respondents were asked about demographic aspects, HIV and AIDS related knowledge ${ }^{11}$, perceived risk of HIV and AIDS, sexual behavior with regular and casual female and male partners (assessed within the previous three months), sexual orientation, and use of alcohol and other drugs.

Statistical analyses were performed using the SPSS ${ }^{\mathrm{x}}$ for main frame ${ }^{24}$. The difference between the means of two independent groups was tested using the $\mathbf{t}$ test procedure. Categorical data were compared using Chi-square.

\section{RESU LTS}

\section{Sample Characteristics}

The mean age for the sample was 30 years $(\mathrm{SD}=$ $8.51 ;$ range $=15-69$ years $).$ Among 232/236 $(98.3 \%)$ 
of literate respondents, the mean period of education was 9.54 years $(\mathrm{SD}=3.7$; range $=1-16)$. Of the total sample, $184(78 \%)$ were single, 34 (14.4\%) were married/lived together, $15(6.4 \%)$ were separated/ divorced, and $3(1.3 \%)$ were widowers. Of the 236 respondents, $171(72.5 \%)$ were employed, 57 $(24.2 \%)$ were unemployed and $8(3.4 \%)$ were retired.

Eighty-five/236 (36\%) defined themselves as heterosexuals, 86/236 (36.4\%) as homosexuals, 27/ $236(11.4 \%)$ as bisexuals and 38/236 (16.1\%) used other expressions.

Of the total sample, $150(63.5 \%)$ were HIV- and $86(36.4 \%)$ were HIV+. The mean length of time since diagnosis was 101.27 weeks $(\mathrm{SD}=115.68)$ with a range from less than a week to 416 weeks.

\section{Sexual Behavior}

Of the $150 \mathrm{HIV}$ - and $86 \mathrm{HIV}+, 114$ (76\%) and $68(79 \%)$ respectively reported sexual contact with female partners at some time in their lives. Sexual contact with male partners was reported by $104 / 150$ (69.3\%) HIV- and by 68/86 (79\%) HIV+.

Fifty-three/114 (46.4\%) HIV- and 18/68 (26.4\%) $\mathrm{HIV}+$ had engaged in sexual contact with regular female partners within the previous three months $\left(\mathrm{x}^{2}\right.$ $=7.17$, df $=1, \mathrm{p}<.01)$. However, the two groups did not significantly differ in the proportion of respondents who had engaged in sexual contact with casual female partners within this time period. Of the $114 \mathrm{HIV}$ - and $68 \mathrm{HIV}+, 26(22.8 \%)$ and 10 $(14.7 \%)$ respectively had engaged in sexual contact with this type of partner.

Of the 104 HIV- and 68 HIV+ who reported same gender sexual contact at some time in their lives, 51 $(49 \%)$ and $31(45.5 \%)$ respectively reported sexual contact with regular male partners within the previous three months. The same number of HIVrespondents $(51,49 \%)$ and $26(38.2 \%) \mathrm{HIV}+$ reported sexual contact with casual male partners.

The number of regular and casual female partners was not found to differ significantly between groups. Among the $53 \mathrm{HIV}$ - the mean number of regular female partners was 1.09 ( $\mathrm{SD}=0.29$; range $=1-2$ ). Among the $18 \mathrm{HIV}+$ the mean was $1.05(\mathrm{SD}=0.23$; range $=1-2$ ). The mean number of casual female partners was $1.65(\mathrm{SD}=1.12$; range $=1-4)$ among the $26 \mathrm{HIV}$-. Of the $10 \mathrm{HIV}+$ the mean was 1.7 (SD $=0.82$; range $=1-3$ ). The number of regular and casual male partners was also not found to differ significantly as between groups. The mean number of regular male partners for the $51 \mathrm{HIV}$ - was 1.11 $(\mathrm{SD}=0.38$; range $=1-3)$. Of the $31 \mathrm{HIV}+$ the mean was $1.19(\mathrm{SD}=0.60$; range $=1-4)$. The mean number of casual male partners was 34.94 (SD = 118.84; range $=1-720$ ), among the 51 HIV-. Of the $26 \mathrm{HIV}+$ the mean was $11.58(\mathrm{SD}=35.06$; range $=1-180)$.

The proportion of respondents in the two serostatus groups who had engaged in the various sexual practices assessed (passive and active oral sex, anal intercourse, and passive and active masturbation) with regular and casual female and male partners was not significantly different between groups except for the proportion of men who had engaged in vaginal intercourse with regular female partners $\left(\mathrm{x}^{2}=5.52, \mathrm{df}=1, \mathrm{p}<.01\right)$. It was reported by $52 / 53(98.1 \%) \mathrm{HIV}$ - and by $15 / 18(83.3 \%) \mathrm{HIV}+$. In relation to frequency of the practices, and number of partners with whom the sexual acts had been performed, the two serostatus groups were also found not to differ either with regular or casual female or male partners.

The sexual behavior of the two serostatus groups with regular and casual female and male partners within the previous three months are presented in Tables 1 and 2. These tables indicate the number and percentage of respondents engaging in the sexual practices investigated. They also display the mean frequency of each practice, and the mean number of regular and casual female and male partners with whom the acts had been performed.

\section{Condom U se}

Overall, respondents in both groups reported high levels of condom use and no significant differences were found between groups on condom use. Both groups tended to use condoms more frequently with casual partners than with regular ones. Table 3 presents the number and percentage of respondents reporting condom use for vaginal and anal intercourse with regular and casual female and male partners.

The statistical analyses on condom use for vaginal intercourse with casual partners, for anal intercourse either with regular or casual female partners, and on condom use for insertive anal intercourse with casual male partners are questionable in view of the small number of respondents engaging in this sexual practice.

\section{Total N umber of Casual Partners}

Was analyzed by adding the number of casual female and male casual partners with whom respondents had engaged in sexual contact within the previous three months. The total number of casual 


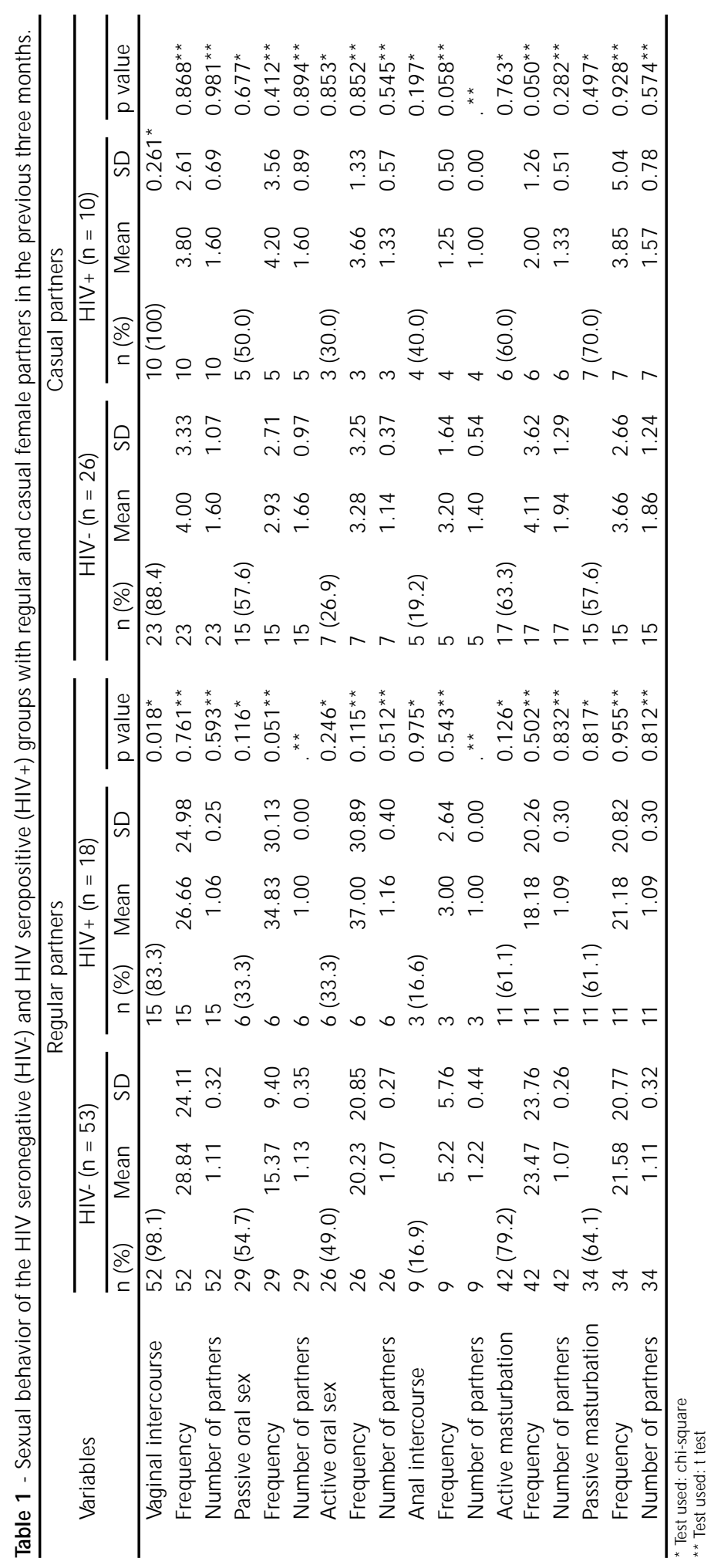




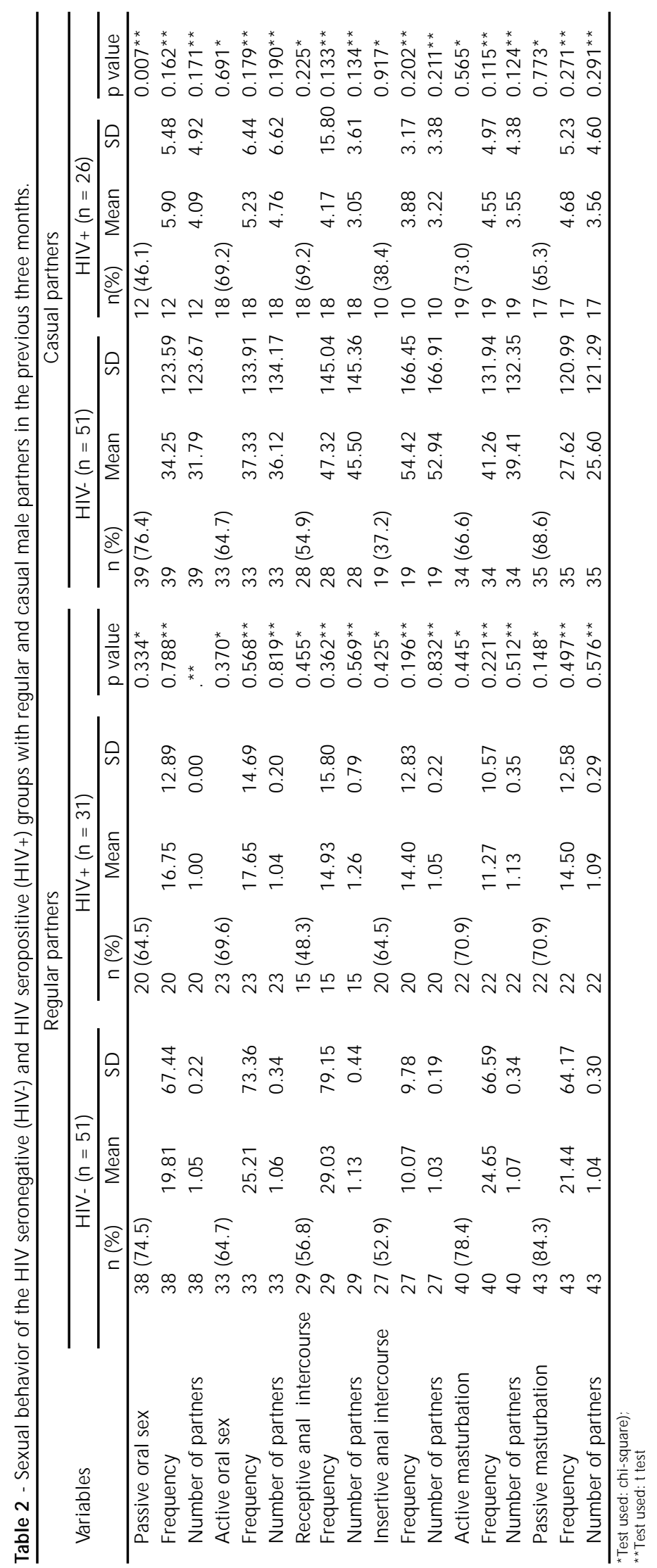


Table 3 - Frequency of condom use during vaginal and anal intercourse with regular and casual female and male partners among HIV seronegative (HIV-) and seropositive (HIV +) reporting these sexual practices within the previous three months.

\begin{tabular}{|c|c|c|c|c|c|}
\hline \multirow[t]{2}{*}{ Condom use } & \multicolumn{3}{|c|}{ FrequencyRegular partnersCasual partners } & \multirow[b]{2}{*}{$\begin{array}{c}\text { HIV- }(n=23) \\
n(\%)\end{array}$} & \multirow[b]{2}{*}{$\begin{array}{c}\mathrm{HIV}+(\mathrm{n}=10) \\
\mathrm{n}(\%)\end{array}$} \\
\hline & & $\begin{array}{c}\text { HIV- }(n=52) \\
n(\%)\end{array}$ & $\begin{array}{c}\mathrm{HIV}+(\mathrm{n}=15) \\
\mathrm{n}(\%)\end{array}$ & & \\
\hline \multirow[t]{5}{*}{ Vaginal intercourse* } & Never & $22(44.3)$ & $1(6.6)$ & $9(39.1)$ & $2(20.0)$ \\
\hline & Sometimes & $19(36.5)$ & $3(20.0)$ & $4(17.3)$ & $2(20.0)$ \\
\hline & Always & $11(21.1)$ & $11(73.3)$ & $10(42.4)$ & $6(60.0)$ \\
\hline & & HIV- $(n=9)$ & $\mathrm{HIV}+(\mathrm{n}=3)$ & HIV- $(n=5)$ & $\mathrm{HIV}+(\mathrm{n}=4)$ \\
\hline & & $\mathrm{n}(\%)$ & $\mathrm{n}(\%)$ & $\mathrm{n}(\%)$ & $\mathrm{n}(\%)$ \\
\hline \multirow[t]{4}{*}{ Anal intercourse with female partners } & Never & $5(55.5)$ & $1(33.3)$ & $2(40.0)$ & $2(50.0)$ \\
\hline & Sometimes & $2(22.2)$ & 0 & 0 & 0 \\
\hline & Always & $2(22.2)$ & $2(66.6)$ & $3(60.0)$ & $2(50.0)$ \\
\hline & & $\begin{array}{c}\text { HIV- }(n=29) \\
n(\%)\end{array}$ & $\begin{array}{c}\mathrm{HIV}+(\mathrm{n}=15) \\
\mathrm{n}(\%)\end{array}$ & $\begin{array}{c}\text { HIV- }(n=28) \\
n(\%)\end{array}$ & $\begin{array}{c}\mathrm{HIV}+(\mathrm{n}=18) \\
\mathrm{n}(\%)\end{array}$ \\
\hline \multirow[t]{4}{*}{ Receptive anal intercourse } & Never & $6(20.6)$ & $3(20.0)$ & $4(14.2)$ & $3(16.6)$ \\
\hline & Sometimes & $4(13.7)$ & $4(26.6)$ & $3(10.7)$ & $3(16.6)$ \\
\hline & Always & $17(58.3)$ & $8(53.3)$ & $21(75.0)$ & $12(66.6)$ \\
\hline & & $\begin{array}{c}\text { HIV- }(n=27) \\
n(\%)\end{array}$ & $\begin{array}{c}\mathrm{HIV}+(\mathrm{n}=20) \\
\mathrm{n}(\%)\end{array}$ & $\begin{array}{c}\text { HIV- }(n=19) \\
n(\%)\end{array}$ & $\begin{array}{c}\mathrm{HIV}+(\mathrm{n}=10) \\
\mathrm{n}(\%)\end{array}$ \\
\hline \multirow{3}{*}{$\begin{array}{l}\text { Insertive anal intercourse } \\
\text { with male partners }\end{array}$} & Never & 5 (18.5) & $4(20.0)$ & $2(10.5)$ & 0 \\
\hline & Sometimes & $2(7.4)$ & $6(30.0)$ & $1(5.2)$ & $1(10.3)$ \\
\hline & Always & $20(74.0)$ & $10(50.0)$ & $16(84.2)$ & $9(90.0)$ \\
\hline
\end{tabular}

$* p<.001$ for vaginal intercourse with regular partners

partners ranged from 0 to 724 . The scores 724, 400, 240,180 and 140 each had a frequency of $1(0.4 \%)$ of the study population and were recoded to the score 100. The mean on total number of casual partners was $4.8(\mathrm{SD}=18.22)$ among the $150 \mathrm{HIV-}$. Of the $86 \mathrm{HIV}+$, the mean was $2.75(\mathrm{SD}=11.47)$. No significant difference between groups was found in this respect.

\section{Sexual Activity}

The HIV- and HIV+ groups were found significantly to differ in terms of sexual activity. This variable was created by computing every kind of sexual practice in which respondents had engaged with every type of partner within the previous three months. A significantly higher proportion of respondents in the HIV- group had engaged in some sexual activity $\left(\mathrm{x}^{2}=10.68, \mathrm{df}=1, \mathrm{p}<.001\right)$. Among the 150 HIV-, $132(88 \%)$ reported some sexual activity, whereas of the $86 \mathrm{HIV}+, 61(70.9 \%)$ did so.

\section{Frequency of Penetrative Sexual Practices}

A significantly higher frequency of penetrative practices was reported by the HIV-group compared to the HIV+ group $(\mathrm{t}=2.28, \mathrm{df}=220.49, \mathrm{p}<.05)$. This variable was created by computing the frequency of vaginal and anal intercourse with regular and casual female partners and the frequency of receptive and insertive anal intercourse with regular and casual male partners. The frequency ranged from 0 to 1860 . The three scores of 150,490 and 1860 , which corresponded to a rate of $1(0.4 \%)$ of the study population, were recoded to a score equal to 100 in order to avoid distortions in the analysis. Among 149 HIV- (1 case of missing data), the mean frequency of penetrative sex was $19.45(\mathrm{SD}=26.24)$. Of 85 $\mathrm{HIV}+$ (1 case of missing data), the mean was 12.71 $(\mathrm{SD}=18.73)$.

\section{DISCUSSIO N}

The main hypothesis of this cross-sectional study was that seropositives would report safer sexual behavior than seronegatives due to concern about transmitting the virus. Previous research has documented a greater reduction in the number of partners ${ }^{2,27}$ and a greater decrease in unprotected anal intercourse $\mathrm{e}^{8,17,20,26}$ among seropositives as compared with seronegatives.

\section{Sexual Behavior with Female Partners}

The analysis of the sexual behavior of the two serostatus groups with both regular and casual female partners included behaviorally heterosexual and bisexual men.

Although it was found that a significant by lower proportion of seropositives than seronegatives engaged in vaginal intercourse with regular partners 
$(\mathrm{p}<.01)$ they did not do so less frequently. It is possible that reduction of vaginal intercourse with regular partners may have been difficult in the context of lengthy or intimate relationships. Further, it may have been considered that use of condoms made sex with regular partners safe, and therefore that frequency per se of the behavior failed to contribute to risk level.

With casual female partners, the two serostatus groups were found not to differ either in proportion of men engaging in vaginal intercourse or in the number of occasions on which this practice was performed. It is possible that any perceived risk to one's own health among a seronegative population would not be evident for seropositives as infection had already taken place, thus reducing the perceived barriers of frequent vaginal intercourse for seropositives.

No significant differences between the two groups were found in terms of either number of people who engaged in anal intercourse or in the frequency of the behavior with either regular or casual female partners. This finding suggests that those who engaged in this sexual activity tended to do so regardless of their HIV status. It should be noted, however, that the number of respondents in both serostatus groups reporting this practice was small, which may limit the force of any conclusion.

Levels of condom use with female partners in this study tended to be high regardless of HIV status. This finding is of particular importance since the use of condoms may be the most effective means of HIV prevention.

The proportion of seronegatives using condoms on all occasions of vaginal intercourse with regular partners $(21 \%)$ was higher than that reported in a study among male heterosexuals attending a genitourinary clinic where approximately $8 \%$ of the men always used condoms with current regular partners $^{23}$. The proportion of seronegatives always using condoms with casual partners (42\%) was higher than that of the same study ${ }^{23}$, of which approximately $7 \%$ always used condoms with non-regular partners.

The differences between findings relating to condom use in this study and in the study cited may be due to inclusion of behaviorally bisexual men in this study. Further, social acceptance of condoms at the time of the present study may have been greater than that at the times of the previously cited research projects.

Comparison between seronegatives and seropositives in condom use for vaginal intercourse with regular partners revealed a significant difference in behavior. However, the use of condoms for vaginal intercourse with casual partners was not found to be significantly different between seronegatives and seropositives. The lack of difference between the two serostatus groups on condom use with casual partners may have been due to a desire among seronegatives to preserve their current serostatus, a commitment which could have motivated condom use as effectively as could concern among the seropositives about infecting others.

Seropositives and seronegatives were found not to differ in condom use for anal intercourse either with regular or casual female partners. Lack of difference between groups on condom use for anal intercourse may be due to the frequency of this practice. Considering that this was low with both regular and casual female partners, it is possible that men of both groups took risks due to a perception that lower frequency equals lower risk. These results should, however, be interpreted with caution due to the small number of respondents engaging in anal intercourse with female partners.

Despite the fact that a substantial proportion of both serostatus groups used condoms, it was observed that some men, particularly seronegatives, never used them at all. Approximately $44 \%$ of seronegatives reported never using condoms for vaginal intercourse with regular partners, and about $40 \%$ never using them with casual partners. In contrast, approximately $7 \%$ of seropositives reported never using condoms for vaginal intercourse with regular partners and $20 \%$ never using them with casual partners.

The failure to use condoms with regular female partners may be associated with several factors. One possible explanation is that since the mean number of regular female partners was approximately one for both groups, seronegatives may not have perceived risk with a regular partner. Another possible explanation may concern the relationship between partners. Trust and fidelity have been associated with not using condoms among heterosexuals ${ }^{15}$. One may feel that more is known about the partner if the relationship is close. For seropositive men, it may be hypothesized that condom use was related to the serostatus of the regular partner. Studies among homosexual men have revealed that awareness of the serostatus of a partner is more likely if the partner is a regular one ${ }^{16}$. Further, studies among HIV positive heterosexuals have revealed that condom use is less likely to occur with a partner of the same serostatus ${ }^{28}$. Although such a partner's status was not assessed in this study, it is likely that respondents had the same serostatus and therefore 
perceived no risk in engaging in unprotected intercourse.

Failure to use condoms with casual female partners among seronegatives may be associated with other factors, such as a belief that condoms are unnatural and spoil spontaneity and pleasure ${ }^{15}$. The fact that approximately a quarter of seropositives never used condoms with casual female partners is a cause for concern. Although the serostatus of the casual partner was also not assessed in this study, it is unlikely that respondents knew the serostatus of a casual partner and or that these information had been shared. Poor communication skills and lack of communication about desires regarding safe sexual behavior have been associated with unsafe sexual behavior ${ }^{3,10}$ and these may have been factors influencing failure to use condoms among seropositives. Another plausible explanation may be associated with time of diagnosis. Accordingly to the design of the study, sexual behavior was assessed within the previous three months. Some respondents knew their seropositive status at the time the study was carried out, but not necessarily at the time of sexual contact. It is possible that they were unaware of their serostatus during this period.

\section{Sexual Behavior with Male Partners}

Comparison between the two serostatus groups of sexual behavior with both regular and casual male partners included behaviorally homosexuals and bisexuals.

Although a relatively low proportion of respondents reported receptive anal intercourse with regular partners, it was higher than that found in a cohort study in Vancouver ${ }^{20}$. These authors found that approximately $11 \%$ and $16 \%$ of seronegatives and of seropositives respectively reported at their last visit usually engaging in receptive anal intercourse. In the present study, more than half of seronegatives and approximately half of seropositives reported receptive anal intercourse. The proportion of seronegatives in this study engaging in receptive anal intercourse with casual partners was also higher than that found among seronegative homosexuals in other studies $^{2,29}$. Calzavara et al. ${ }^{2}$ reported that approximately $20 \%$ of seronegatives engaged in this sexual practice, and Wiktor et al. ${ }^{29}$ that $26 \%$ did so with more than one partner. The present study found approximately more than half of seronegatives engaged in receptive anal intercourse. The proportion of seropositives in the present study reporting engaging in receptive anal intercourse with casual partners was also higher than the approximately $46 \%$ reported by Calzavara et al. ${ }^{2}$ and the $43 \%$ reported by Wiktor et al. ${ }^{29}$. In the present study, approximately $70 \%$ were found to have practiced receptive anal intercourse with casual partners.

The proportion of seronegatives engaging in insertive anal intercourse with casual male partners in the present study (approximately 37\%) was similar to that reported in a study of homosexual men', in which approximately $35 \%$ of the sample reported engaging in this activity. Of seropositives, however, Calzavara $e t ~ a l .2$ reported almost half to engage in insertive anal intercourse, whereas the present study reported only $38 \%$ to do so.

The lack of significant difference between the two groups on receptive or insertive anal intercourse as a proportion of respondents engaging in this sexual practice or frequency of these acts either with regular or casual male partners suggests that HIV status has little or no influence on the sexual behavior of men who engage in same gender sexual contact. It may be hypothesized that failure of seropositives to engage in less anal intercourse may be due to the high level of condom use identified by the study, as this safe sex practice may have reduced the perceived threat of such behavior.

Some studies have reported that seropositive male homosexuals and bisexuals are more likely to use condoms than seronegatives ${ }^{8,17,26}$. In this study condom use for anal intercourse with male partners was high for both serostatus groups, and no significant difference between groups was found. This finding is, however, consistent with a more recent study, where seronegative and seropositive homosexuals were not found to differ in condom use ${ }^{9}$.

The absence of differences between the two serostatus groups on condom use in the present study in contrast with the significant differences found in the earlier studies cited may be related to the time of the field work. A wareness of the threat of AIDS over the years may have increased preventive behavior in both serostatus groups.

Consistent with findings of previous studies of homosexual and bisexual males ${ }^{1,16}$ the present study reported that both groups were less likely to use condoms for anal intercourse with regular partners than with casual ones. Previous work ${ }^{7,16}$ has suggested that unprotected intercourse with regular partners is not perceived as risky because emotional involvement between the partners may decrease the perception of risk. Further, the HIV status of a regular partner is more likely to be known in a context of 
regular relationship. The findings in the present study support this view.

Despite high levels of condom use with male partners found in this study, it is clear that the practice of sex was not exclusively safe. Approximately $20 \%$ of both seronegatives and seropositives never used condoms for receptive anal intercourse with regular partners and approximately $16 \%$ with casual partners. For insertive anal intercourse approximately $20 \%$ of the seronegatives and seropositives never used condoms with regular partners. Of seronegatives reporting insertive anal intercourse with casual male partners, approximately $10 \%$ never used condoms for this practice.

Failure to use condoms for receptive and insertive anal intercourse with regular male partners may have been associated with knowledge of partner's serostatus. The extent to which participants shared the same HIV status as the partner was not established in the present study, but it has been reported that unprotected anal intercourse among homosexual men is more likely to occur when partners are of the the same serostatus ${ }^{14}$. Respondents may have viewed unprotected intercourse with a partner of the same serostatus as safe. Another possible explanation may be related to personal involvement. Having strong commitment in a relationship or being in love has been associated with unprotected anal intercourse ${ }^{10,16}$, and it may be hypothesized that such factors were effective in the present study.

Perceived difficulty in modifying sexual behavior ${ }^{22}$, early history of frequent high risk sexual behavior $^{13}$ and negative connotations of condom use $^{6,12}$ have all been associated with unprotected anal intercourse. Such factors may have contributed to failure to use condoms in the present study.

\section{Total N umber of Casual Partners, Sexual Activity and Frequency of Penetrative Practices}

The results indicated that although the mean number of casual partners was lower among seropositives than seronegatives, this difference did not reach statistical significance. Other studies ${ }^{25,29}$ have also reported no significant difference between seronegatives and seropositives in number of partners. It may be hypothesized that seropositives failed to have significantly fewer casual partners than seronegatives due to high levels of condom use as a means of HIV prevention. Another possible explanation may have been associated with the perception that a large number of casual partners increases the risk of HIV infection. One of the aspects raised by earlier HIV and AIDS prevention campaigns in Brazil was the importance of reducing the number of partners, particularly anonymous partners. It may be that men have reduced their number of casual partners over the years following these guidelines.

The results on levels of sexual activity indicated that a significantly higher proportion of seronegatives compared to seropositives engaged in some sexual activity. This may suggest that some seropositive men due to their HIV status were more likely to reduce or to have stopped engaging in sexual activity than the seronegative ones. Wenger et al. ${ }^{28}$ reporting on a sample of HIV positive heterosexuals found that of respondents with no sexual partner, $74 \%$ had stopped all sexual activity due to the HIV test result.

The results also demonstrated that seropositives reported a significantly lower frequency of penetrative practices with regular and casual partners than did seronegatives. This suggests that seropositive men may have tended to reduce frequency of practices more likely to pose risk for HIV transmission.

Analyses carried out on individual sexual practices separately, however, failed to reveal significant differences between groups, either in terms of proportion of respondents engaging in the sexual practices or frequency of the acts, as has been previously noted. The exception to this was vaginal intercourse, in which a lower proportion of seropositive respondents were found to engage with regular partners. One possible explanation for the significant differences is that the sample size involved when all the variables were categorized together for analysis yielded a higher power allowing detection of this difference.

This study is unique in its comparison of seronegative and seropositive males in Brazil. However, there are some limitations concerning these data.

This study was carried out in the major urban state in Brazil. Cultural and social differences vary greatly in a country as vast as Brazil. These cultural differences should be taken into consideration when examining the sexual behavior of men in any country and specific studies should consider sub cultural differences within Brazil.

A sample of seronegative men who have chosen to undergo testing cannot be assumed to be representative of the entire seronegative population, as the factors influencing the decision to take a test may themselves reflect previous sexual behavior. It is conceivable, for example, that HIV seronegative 
men who undergo testing may have practiced less safe sex than those who chose not to be tested. Future research in Brazil should aim also to investigate the sexual behavior of people at low risk of HIV infection.

The present study, like many others investigating behavioral factors contributing to HIV transmission, was based on information reported by respondents. This may have led to some inconsistencies between respondents' actual and self-reported respondent behavior. However, both interviews and selfadministrated questionnaires can provide reasonable data on sexual behavior when short periods of recall are covered ${ }^{4,21}$.

This study has allowed effective observation of sexual behavior among males in S. Paulo. Such work may provide a valuable basis for future intervention. Areas of sexual behavior found not to be practiced safely may be subject to such future work. The motivation that influences riskier sexual behavior with regular partners may be addressed through qualitative studies.

\section{CONCLUSIONS}

This study has found that HIV seropositives reported lower levels of some sexual activity and lower frequency of penetrative practices than HIV seronegatives. Safer sex education programs should strive not only to encourage HIV negative individuals to practice safer sex in order to maintain their current healthy status, but also to encourage HIV positive individuals to do so in order to prevent further transmission of the virus. An optimistic interpretation

\section{REFEREN CES}

1. BOULTON, M. et al. The sexual behaviour of bisexual men in relation to HIV transmission. AIDS Care, 4:165-75, 1992.

2. CALZAVARA, L. M. et al. Sexual behaviour changes in a cohort of male sexual contacts of men with HIV disease: a three year overview. Can. J. Public Health, 82:150-6, 1991.

3. CATANIA, J.A. et al. Condom use in multi-ethnic neighborhoods of San Francisco: the population-based AMEN (AIDS in multi-ethnic neighborhoods) study. Am. J. Public Health, 82: $284-7,1992$.

4. COATES, R.A. et al. Validity of sexual histories in a prospective study of male sexual contacts of men with AIDS or AIDS-related condition. Am. J. Epidemiol., 128:719-28, 1988

5. CORTES, E. et al. HIV-1, HIV-2, and HTLV-1 infection in high-risk groups in Brazil. N. Engl. J. Med., 320: 953-8, 1989. of lower risk behavior among seropositives found in the present study may be that some members of this sample were indeed actively changing their behavior to incorporate lower risk in response to their seropositive diagnosis. Such inference remains speculative, however, as it cannot be validated by cross-sectional design. Nevertheless, it is likely that such a change in behavior had occurred as a result of the acquisition of positive status.

One principal component of safer sex education may be the encouragement of condom use. The high level of condom use with female and male partners regardless of HIV status which has been consistently identified throughout this study provides further encouraging evidence that a substantial proportion of men in S. Paulo are taking up such advice. Given that condom use may be a more effective means of protection than reducing number of partners or frequency of sexual acts, this finding is of considerable importance in the context of HIV prevention. However, this study has also revealed that condom use was not universal, and that some men continued to place themselves at risk. Failure to use condoms with regular partners may result from conscious decisions based on assumptions regarding the partner's serostatus and behavioral history, assumptions which may often be inaccurate. Further, the use of condoms is a personal decision and may be influenced by emotional and psychological factors.

\section{ACKN O W LED G EMENTS}

To Elisabeth Meloni, PhD and Patricia Rondo, $\mathrm{PhD}$ for their extremely valuable comments.

6. DE WIT, J.B.F. et al. Why do homosexual men relapse into unsafe sex? Predictors of resumption of unprotected anogenital intercourse with casual partners. AIDS, 7:1113-8, 1993.

7. FITZPATRICK, R. et al. Variation in sexual behaviour in gay men. In: Aggleton, P., Davies, P., Hart, G., ed. AIDS: individual, cultural and policy dimensions. London, The Falmer Press, 1990, p. 121-32.

8. FRAZER, I.H. et al. Influence of human immunodeficiency virus antibody testing on sexual behaviour in a 'high-risk' population from a 'low-risk' city. Med. J. Aust., 149:365-8, 1988.

9. FITZPATRICK, R. et al. Factors influencing condom use in a sample of homosexually active men. Genitourinar: Med., 66: 346-50, 1990. 
10. GOLD, R.S. et al. Situational factors and thought processes associated with unprotected intercourse in gay men. Psychol. Health, 5: 259-78, 1991.

11. KELLY, J.A. et al. An objective test of AIDS risk behavior knowledge: scale development, validation, and norms. $J$. Behav. Ther. Exp. Psychiatry, 20: 227-34, 1989.

12. KELLY, J.A. et al. Situational factors associated with AIDS risk behavior lapses and coping strategies used by gay men who successfully avoid lapses. Am. J. Public Health, 81:1335-8, 1991.

13. KELLY, J.A. et al. Predictors of vulnerability to AIDS risk behavior relapse. J. Consul. Clin. Psychol., 59: 163-6, 1991.

14. KIPPAX, S. et al. Sustaining safe sex: a longitudinal study of a sample of homosexual men. AIDS, 7:257-63, 1993.

15. KIPPAX, S. et al. Heterosexually, masculinity and HIV. AIDS, 8 (Suppl. 1):S315-23, 1994.

16. MCLEAN, J. et al. Regular partners and risk behaviour: why do gay men have unprotected intercourse? AIDS Care, 6: $331-41,1994$

17. MCKUSICK, L. et al. Longitudinal predictors of reductions in unprotected anal intercourse among gay men in San Francisco: the AIDS behavioral research project. Am. J. Public Health, 80: 978-83, 1990.

18. MINISTÉRIO DA SAÚDE. Programa Nacional de Doenças Sexualmente Transmissíveis/AIDS. AIDS Bol. Epidemiol., 9(6), 1997.

19. MOURA, E.M. et al. High rate of HIV seropositivity among persons tested at an anonymous testing center in Rio de Janeiro. In: International Conference on AIDS, 8th Amsterdam, The Netherlands, 1992. Abs. PoC 4054.
20. SCHECHTER, M. T. et al. Patterns of sexual behavior and condom use in a cohort of homosexual men. Am. J. Public Health, 78: 1535-8, 1988.

21. SALTZMAN, S.P. et al. Reliability of self-reported sexua behavior risk factors for HIV infection in homosexual men. Public Health Rep., 102:692-7, 1987.

22. SIEGEL, K. et al. Factors distinguishing homosexual males practicing risky and safer sex. Soc. Sci. Med., 28: 561-9, 1989.

23. SONNEX, C. et al. Condom use by heterosexuals attending a department of GUM: attitudes and behaviour in the light of HIV infection. Genitourin. Med., 65:248-51, 1989.

24. SPSS Statistical Data Analysis - release 4.SPSS Reference guide. [disquete] Chicago, SPSS Inc., 1990.

25. TINDALL, B. et al. Sexual practices and condom usage in a cohort of homosexual men in relation to human immunodeficiency virus status. Med. J. Austr., 151:318-22, 1989.

26. VAN GRIENSVEN, G. J. P. et al. Effect of human immunodeficiency virus (HIV) antibody knowledge on high-risk sexual behavior with steady and nonsteady sexual partners among homosexual men. Am. J. Epidemiol., 129: 596-603, 1989.

27. VAN GRIENSVEN, G. J. P. et al. Changes in sexual behaviour and the fall in incidence of HIV infection among homosexual men. $B M J, \mathbf{2 9 8}: 218-21,1989$.

28. WENGER, N.S. et al. Sexual behavior of individuals infected with the human immunodeficiency virus. Arch. Intern. Med., 154: 1849-54, 1994.

29. WIKTOR, S.Z. et al. Effect of knowledge of human immunodeficiency virus infection status on sexual activity among homosexual men. J. Acquir. Immune. Defic. Syndr., 3:62-8, 1990 . 